\title{
PENGGUNAAN MODEL PEMBELAJARAN TIPE COOPERATIVE INTEGRATED READING AND COMPOTITION (CIRC) SEBAGAI UPAYA MENINGKATKAN PRESTASI BELAJAR BAHASA INDONESIA
}

\author{
Ni Ketut Sukarini \\ SD Negeri 3 Sukawati \\ nktsukarini@gmail.com
}

\begin{abstract}
Abstrak
Penelitian ini dilaksanakan di SD Negeri 3 Sukawati di kelas II C Semester II Tahun Pelajaran 2017/2018 yang kemampuan siswanya untuk mata pelajaran Bahasa Indonesia masih rendah. Tujuan penulisan penelitian tindakan kelas ini adalah untuk mengetahui apakah penggunaan Model Pembelajaran Tipe Cooperative Integrated Reading and Compotition (CIRC) dapat meningkatkan prestasi belajar siswa. Metode pengumpulan datanya adalah tes prestasi belajar. Metode analisis datanya adalah deskriptif. Hasil yang diperoleh dari penelitian ini adalah penggunaan Model Pembelajaran Tipe Cooperative Integrated Reading and Compotition (CIRC) dapat meningkatkan prestasi belajar siswa. Ini terbukti dari hasil yang diperoleh pada pada awalnya 58,00 setelah diberikan tindakan pada siklus I meningkat menjadi 63,6 dan pada siklus II meningkat lagi menjadi 75,8. Kesimpulan yang diperoleh dari penelitian ini adalah penggunaan Model Pembelajaran Tipe Cooperative Integrated Reading and Compotition (CIRC) dapat meningkatkan prestasi belajar Bahasa Indonesia siswa kelas II C SD Negeri 3 Sukawati semester II Tahun Pelajaran 2017/2018.
\end{abstract}

Kata kunci: Model Pembelajaran Tipe Cooperative Integrated Reading and Compotition (CIRC), Prestasi Belajar Bahasa Indonesia.

\begin{abstract}
This research was conducted at SD Negeri 3 Sukawati in class II C Semester II of the Academic Year 2017/2018 where the ability of students for Indonesian subjects was still low. The purpose of writing this class action research is to find out whether the use of Cooperative Integrated Reading and Compotition (CIRC) Learning Models can improve student achievement. The data collection method is a learning achievement test. The data analysis method is descriptive. The results obtained from this study are the use of Cooperative Integrated Reading and Compotition (CIRC) Learning Model can improve student learning achievement. This is evident from the results obtained initially at 58.00 after being given action in the first cycle increased to 63.6 and in the second cycle increased again to 75.8 . The conclusion obtained from this study is the use of Cooperative Integrated Reading and Compotition (CIRC) Learning Model can improve the learning achievement of Indonesian students in class II C of SD Negeri 3 Sukawati in the second semester of 2017/2018 Academic Year.
\end{abstract}

Keywords: Cooperative Integrated Reading and Compotition (CIRC) Learning Model, Indonesian Language Learning Achievement.

\section{Pendahuluan}

Pembangunan nasional dilaksanakan dalam rangka membangun manusia Indonesia seutuhnya dan pembangunan masyarakat Indonesia seluruhnya. Hal ini berarti bahwa pembangunan itu tidak hanya mengejar lahiriah seperti sandang, pangan, perumahan, kesehatan, dan sebagainya atau kepuasan batiniah saja seperti pendidikan, rasa aman, bebas mengeluarkan pendapat dan sebagainya, melainkan juga keselarasan, keserasian, dan keseimbangan antara keduanya.

Dalam rangka menciptakan manusia seutuhnya maka pembangunan pendidikan merupakan bidang yang penting untuk mendapatkan prioritas. Hubungan dengan hal tersebut, maka pendidikan memerlukan konsep yang baku sehingga pelaksanaan sistem pendidikan dapat menciptakan manusia yang siap pakai. Tujuan pendidikan nasional berdasarkan UU sistem penddidikan nasional tahun 2003 dinayatakan bahwa Pendidikan Nasional berfungsi mengembangkan kemampuan dan membentuk watak serta peradaban bangsa yang bermartabat dan dalam rangka mencerdaskan kehidupan bangsa, bertujuan untuk berkembangnya potensi peserta didik agar menjadi manusia yang beriman dan bertakwa kepada Tuhan Yang Maha Esa, berakhlak mulia, sehat, berilmu, cakap, kreatif, mandiri, dan menjadi warga negara yang demokratis serta bertanggung jawab (SPN, 2003: 7).

Dikatakan bahwa pendidikan itu berlangsung seumur hidup dan dilaksanakan dalam keluarga, sekolah dan masyarakat, karena itu pendidikan merupakan tanggung jawab bersama antara keluarga, masyarakat, dan pemerintah. Dengan demikian unsur keluarga merupakan hal yang penting sebelum mengarah lebih lanjut pada sekolah dan masyarakat. Mengingat pentingnya peranan keluarga itu terhadap pendidikan terutama terhadap 
anak-anaknya. Peranan orang tua yang langsung terhadap anak-anaknya juga adalah mendidik untuk menciptakan ilmu yang berguna baik melalui sekolah yang berlangsung secara terus menerus maupun di lingkungan masyarakat di mana ia berada. Hal ini berarti penyediaan materi dan spirit anak-anaknya turut menentukan, termasuk mengawasi hal-hal yang tidak diinginkan agar tujuan mewujudkan anak yang soleh dapat tercapai.

Guru wajib menciptakan suasana pendidikan yang bermakna, menyenangkan, kreatif, dinamis, dialogis, berkomitmen meningkatkan mutu pendidikan, memberi tauladan, menjaga nama baik lembaga. Guru berperan untuk mampu melakukan interaksi, pengasuhan, mengatur tekanan, memberi fasilitas, perencanaan, pengayaan, menangani masalah, membimbing dan memelihara. Dengan guru memahami tugas-tugas tersebut dan memahami apa yang mesti dilakukan tentu saja kondisi yang diharapkan dalam pembelajaran di sekolah dasar akan dapat terlaksana dengan baik. Selain memahami hal-hal tersebut, guru juga harus mengetahui faktor-faktor yang mempengaruhi pertumbuhan 0anak (Yamin dan Sanan, 2013: 30-32).

Dari semua kutipan di atas jelaslah kondisi yang diharapkan dalam pembelajaran bagi anak-anak SD, untuk itu guru harus mampu melaksanakannya agar peningkatan mutu pendidikan dapat dicapai sesuai harapan. Kenyataan yang ada di lapangan ternyata tidak sesuai dengan semua harapan tadi, ini terlihat pada data awal penilaian kemampuan berbahasa anak SD Negeri 3 Sukawati kelas II C Semester II Tahun Pelajaran 2017/2018 yang diukur menggunakan kriteria penilaian bercerita setelah dilakukan metode karya wisata. Mengacu kriteria penilaian yang ditetapkan, kemampuan mereka baru mencapai rata-rata 58,18.

Kondisi tersebut jika dibiarkan, dapat memunculkan masalah baru yang lebih serius dan dikhawatirkan dapat mengganggu perkembangan kemampuan anak secara menyeluruh. Sehingga sebagai seorang guru harus berupaya untuk memecahkan masalah yang ada. Untuk hal tersebut peneliti mencoba mengintensifkan penggunaan Model Pembelajaran Tipe Cooperative Integrated Reading and Compotition (CIRC) untuk mengupayakan peningkatan prestasi belajar anak.

Mengingat permasalahan yang ada adalah permasalahan yang mendesak untuk dipecahkan maka penelitian ini menjadi penting untuk dilaksanakan.

\section{METODE}

Penelitian Tindakan Kelas (PTK) ini dilaksanakan di SD Negeri 3 Sukawati yang berlokasi di Kabupaten Gianyar. Jadwal pelaksanaan penelitian ini adalah pada semester Genap tahun pelajaran 2017/2018. Untuk penelitian ini penulis memilih rancangan penelitian tindakan yang disampaikan oleh Mc. Kernan seperti terlihat pada gambar berikut.

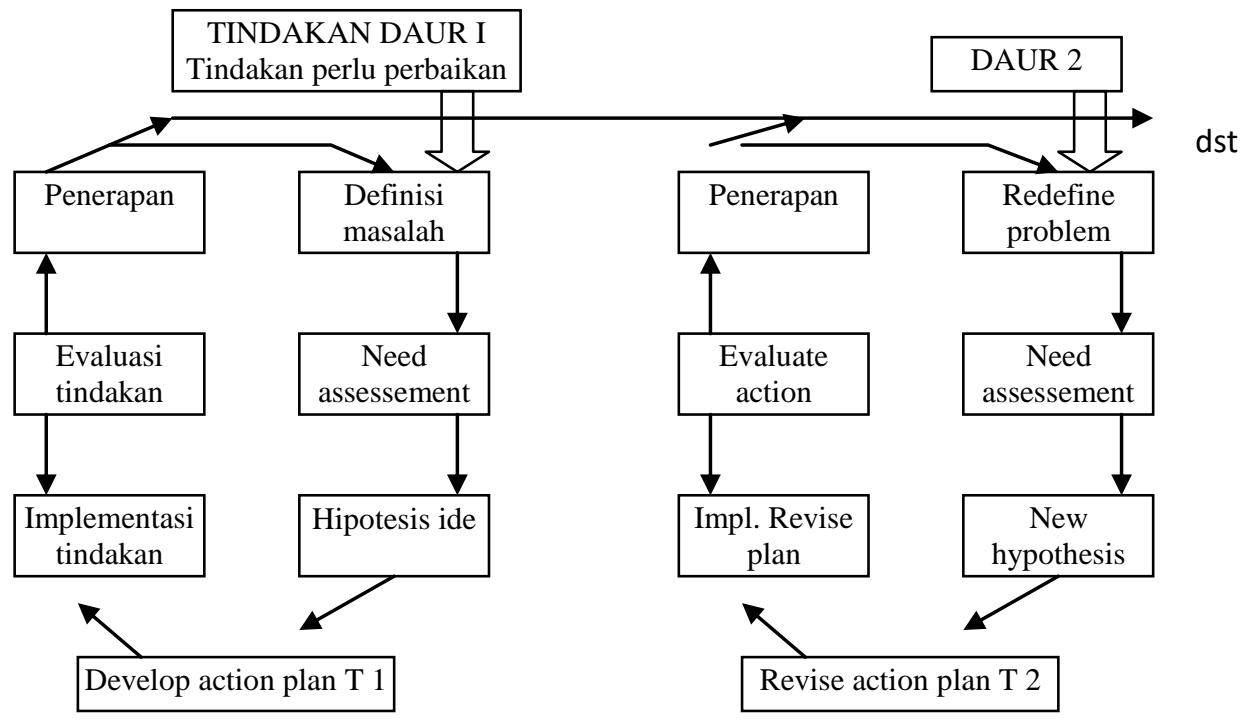

Gambar 01. Penelitian Tindakan Model Mc. Kernan, 1991 (dalam Sukidin, Basrowi, Suranto, 2002: 54)

Penelitian ini merupakan penelitian tindakan kelas yang akan dilaksanakan dalam dua siklus. Jika pada siklus pertama hasil belajar Seni Budaya siswa belum memenuhi kriteria keberhasilan, maka berdasarkan hasil refleksi akan dilakukan perbaikan pada siklus selanjutnya. Secara operasional prosedur dasar pengembangan tindakan yang akan dilakukan dapat dijabarkan sebagai berikut :Prosedur:

a. Tindakan daur I: mulai dari definisi masalah, berlanjut ke assessment yang disiapkan, berlanjut ke rumusan hipotesis, berlanjut ke pengembangan untuk tindakan I, lalu implementasi tindakan, evaluasi tindakan berlanjut ke penerapan selanjutnya. 
b. Tindakan daur II: mulai dari menentukan kembali masalah yang ada, berlanjut ke assessment yang disiapkan, terus ke pemikiran terhadap munculnya hipotesis yang baru, perbaikan tindakan pada rencana ke 2, pelaksanaan tindakan, evaluasi terhadap semua pelaksanaan dan penerapan.

Prosedur yang dilakukan dengan model ini adalah pada awalnya menemukan kekurangan-kekurangan yang ada, setelah dianalisis ternyata kemampuan anak dalam pelajaran Seni Budaya masih rendah sehingga dibuat perencanaan, dilanjutkan dengan langkah-langkah tindakan yaitu melatih terus sesuai kaidah pembelajaran di SD karena penilaian terhadap kemajuan anak harus diupayakan berkesinambungan, begitu juga penilaiannya. Lara Fridani, dkk (2011:6) mengatakan bahwa assesment perkembangan anak dilaksanakan secara terus menerus dan berkesinambungan. Setelah langkah tindakan dimonitor berserta efeknya serta kegagalannya bisa ditemukan, dibuat revisi untuk perencanaan selanjutnya. Demikian terus bergulir sampai penelitian berhasil sesuai indikator yang diusulkan. Untuk indikator tersebut ada di Bab III ini dibagian yang paling akhir.

Pengumpulan data dalam penelitian ini menggunakan tes prestasi belajar. Untuk menganalisis data hasil penelitian ini digunakan metode deskriptif. Untuk data kuantitatif dianalisis dengan mencari mean, median, modus, membuat interval kelas dan melakukan penyajian dalam bentuk tabel dan grafik.

Indikator keberhasilan penelitian yang diusulkan dalam penelitian ini pada siklus I dan II mencapai nilai rata-rata 75,00 dengan ketuntasan belajar 85\%. dengan KKM yang ditetapkan untuk mata pelarajan Bahasa Indonesia pada SD Negeri 3 Sukawati adalah 65.

\section{Hasil dan Pembahasan}

Deskripsi awal telah menunjukkan rendahnya prestasi belajar siswa yang diakibatkan oleh faktor-faktor luar dan faktor-faktor dari dalam diri guru sendiri. Faktor-faktor tersebut telah dipahami betul dan pelan-pelan diperbaiki agar proses pembelajaran tidak dipengaruhi oleh faktor-faktor tersebut dengan cara membuat perencanaan yang lebih baik pada siklus berikutnya. Dari faktor siswa tentang kurangnya motivasi orang tua dalam mengarahkan anak-anak mereka untuk mau giat belajar dilakukan dengan memberi pengarahan lewat penyampaian yang dilakukan kepala sekolah terhadap orang tua siswa.

Dari hail pengamatan yang telah dilakukan pada siklus I ini dalam upaya pembenahan proses pembelajaran di kelas dapat disampaikan bahwa ada kelebihan-kelebihan yaitu peneliti telah membuat perencanaan yang matang, dengan terlebih dahulu membaca teori yang ada, dalam pelaksanaan pembelajaran peneliti sudah berpakaian rapi, menggunakan bahasa yang santun, menuntun siswa dengan baik. Hal ini menimbulkan nterpretasi bahwa perjalanan penelitian sudah cukup baik. Kelemahan yang disampaikan perlu diberikan analisis yaitu penggunaan waktu yang belum efektif, konstruksi, kontribusi siswa belum maksimal, fakta ini akan dijadikan acuan kebenaran data, validasi internal validitas eksternal berupa penggunaan teori-teori yang mendukung dan reliabilitas data penelitian ini dapat penulis yakini karena hal itu merupakan ketepatan peneliti memilih instrumen. Faktor-faktor yang berpengaruh belum maksimalnya pembelajaran pada siklus I ini adalah karena peneliti baru satu kali mencoba model ini. Cara pemecahan masalahnya adalah penyiapan RPP yang lebih baik, lebih berkualitas, meminta pendapat teman sejawat untuk memperoleh tambahan pengalaman, gambaran-gambaran.

Dari gambaran pelaksanaan yang telah dilakukan ternyata hasil yang diperoleh pada siklus I ini sudah lebih baik dari hasil awal yang baru mencapai nilai rata-rata 58,18 dengan ketuntasan belajar 45,45\%. Pada siklus I ini sudah mencapai peningkatan sedikit lebih tinggi yaitu dengan rata-rata 64,31 dan ketuntasan belajar $68,18 \%$. Namun hasil tersebut belum maksimal karena tuntutan indikator keberhasilan penelitian adalah agar peserta didik mampu memperoleh rata-rata 75,00. Oleh karenanya penelitian ini masih perlu untuk dilanjutkan.

Perolehan hasil dari kegiatan penelitian pada siklus II ini terbukti telah menunjukkan bahwa kemampuan siswa dalam mengikuti pelajaran sudah cukup baik. Ini terbukti dari rata-rata nilai siswa mencapai 76,59 dengan ketuntasan belajar 95,45\%. Hasil ini menunjukkan bahwa Model Pembelajaran Tipe Cooperative Integrated Reading and Compotition (CIRC) telah berhasil meningkatkan kemampuan siswa menempa ilmu sesuai harapan. Model Pembelajaran Tipe Cooperative Integrated Reading and Compotition (CIRC) merupakan metode/model yang cocok bagi siswa apabila guru menginginkan mereka memiliki kemampuan melakukan analisis, sintesis, berargumentasi, mengeluarkan pendapat secara lugas. Model Pembelajaran Tipe Cooperative Integrated Reading and Compotition (CIRC) mampu memupuk kemampuan intelektual siswa, mendorong siswa untuk mampu menemukan sendiri, menempatkan siswa pada posisi sentral dan mengupayakan agar siswa mampu belajar lewat penemuan agar materi yang dipelajari dapat diingiat lebih lama.

Hasil penelitian ini ternyata telah memberi efek utama bahwa model yang diterapkan dalam proses pembelajaran berpengaruh secara signifikan terhadap prestasi belajar siswa. Temuan ini membuktikan bahwa guru sudah tepat memilih metode dalam melaksanakan proses pembelajaran karena pemilihan metode merupakan hal yang tidak boleh dikesampingkan. Hal ini sejalan pula dengan temuan-temuan peneliti lain seperti yang dilakukan oleh Inten (2004) dan Puger (2004) yang pada dasarnya menyatakan bahwa metode pembelajaran yang diterapkan berpengaruh terhadap prestasi belajar siswa. 
Upaya maksimal dalam melaksanakan pembelajaran pada siklus II dengan memperbaiki semua kelemahan-kelemahan sebelumnya telah mampu membuat peningkatan pemahaman dan keilmuan peserta didik. Dari nilai yang diperoleh siswa, lebih setengah siswa mendapat nilai 3 siswa memperoleh nilai sesuai KKM dan 2 siswa memperoleh nilai rendah. Atas dasar perolehan data dalam bentuk nilai tersebut dapat diyakini bahwa prestasi belajar siswa dapat ditingkatkan dengan penggunaan Model Pembelajaran Tipe Cooperative Integrated Reading and Compotition (CIRC).

Melihat perbandingan nilai awal, nilai siklus I dan nilai siklus II, terjadi kenaikan yang signifikan, yaitu dari rata-rata nilai awal adalah 58,18 naik di siklus I menjadi 64,31 dan di siklus II naik menjadi 76,59. Kenaikan ini tidak bisa dipandang sebelah mata karena kenaikan nilai ini adalah dari upaya-upaya yang maksimal yang dilaksanakan peneliti demi peningkatan mutu pendidikan dan kemajuan pendidikan khususnya di SD Negeri 3 Sukawati.

Hasil penelitian ini sejalan dengan hasil penelitian yang dilakukan oleh Anggraeni pada tahun 2017 yang berjudul Upaya Meningkatkan Hasil Belajar Siswa Dengan Menerapkan Model Pembelajaran Kooperatif Tipe CIRC Pada Materi Segitiga dan Segiempat Kelas VII SMP Negeri 6 Kota Bengkulu. Hasil penelitiannya menunjukkan bahwa: peningkatan hasil belajar siswa dapat dilihat dari rata-rata tes hasil belajar (THB) siswa siklus I sampai siklus III yaitu 70,17, 78,91 dan 82,87 dengan presentase ketuntasan belajar klasikal dari siklus I sampai siklus III yaitu 56,52\%, 73,91\%, 82,61\%.

\section{Simpulan}

Simpulan yang dapat disampaikan berdasarkan semua hasil analisis data yang telah dilakukan dengan melihat hubungan rumusan masalah, tujuan penelitian, hipotesis tindakan dan semua hasil pembahasan adalah sebagai berikut:

1. Fokus pembahasan dari penelitian ini adalah untuk membuktikan apakah Model Pembelajaran Tipe Cooperative Integrated Reading and Compotition (CIRC) dapat meningkatkan prestasi belajar siswa kelas II C SD Negeri 3 Sukawati. Dari hasi analisis yang telah dilakukan yang dilanjutkan dengan pembahasan dapat disampaikan bahwa peningkatan hasil belajar telah dapat diupayakan. Dari data awal yang rata-rata baru mencapai 58,18 dan jauh dari kriteria ketuntasan minimal pada mata pelajaran ini, pada siklus I sudah dapat ditingkatkan menjadi 64,31 dan pada siklus II sudah mencapai rata-rata 76,59 . Siswa yang pada awalnya kemampuannya masih sangat rendah dimana hanya ada 10 yang tuntas, pada siklus I sudah dapat ditingkatkan yaitu ada 15 siswa yang sudah tuntas dan pada siklus II sudah 21 yang tuntas. Dari hasil awal ada 12 siswa yang harus diremidi sedangkan pada siklus II hanya 1 siswa yang mesti diremidi.

2. Dari uraian fakta-fakta di atas yang dibarengi dengan penyajian data hasil observasi baik siklus I maupun siklus II telah dapat dibuktikan bahwa Model Pembelajaran Tipe Cooperative Integrated Reading and Compotition (CIRC) dapat meningkatkan kemampuan siswa dalam belajar. Dengan hasil tersebut dapat dibuktikan bahwa rumusan masalah dan tujuan penelitian telah tercapai dan hipotesis yang diajukan sudah dapat diterima. Untuk hal tersebut selanjutnya perlu disampaikan saran.

Berdasarkan temuan yang sudah disimpulan dari hasil penelitian, dalam upaya mencapai tujuan pembelajaran, dapat disampaikan saran-saran sebagai berikut:

1. Bagi guru kelas, apabila mau melaksanakan proses pembelajaran penggunaan metode yang telah diterapkan ini semestinya menjadi pilihan dari beberapa metode yang ada mengingat metode ini telah terbukti dapat meningkatkan kualitas pembelajaran.

2. Bagi peneliti lain, walaupun penelitian ini sudah dapat membuktikan efek utama dari Model Pembelajaran Tipe Cooperative Integrated Reading and Compotition (CIRC) dalam meningkatkan prestasi belajar, sudah pasti dalam penelitian ini masih ada hal-hal yang belum sempurna dilakukan, oleh karenanya kepada peneliti lain yang berminat meneliti topik yang sama untuk meneliti bagian-bagian yang tidak sempat diteliti.

3. Bagi pengembang pendidikan, selanjutnya untuk adanya penguatan-penguatan, diharapkan bagi peneliti lain untuk melakukan penelitian lanjutan guna memverifikasi data hasil penelitian ini.

\section{Daftar Pustaka}

Anggraeni, Sintya Siti, dkk. 2017. Upaya Meningkatkan Hasil Belajar Siswa Dengan Menerapkan Model Pembelajaran Kooperatif Tipe CIRC Pada Materi Segitiga dan Segiempat Kelas VII SMP Negeri 6 Kota Bengkulu. Jurnal Penelitian Pembelajaran Matematika Sekolah (JP2MS), Vol. 1, No. 1, Agustus 2017.

Arikunto, Suharsimi; Suhardjono; Supardi. 2006. Penelitian Tindakan Kelas. Jakarta: PT Bumi Aksara.

Badan Standar Nasional Pendidikan. 2007. Peraturan Menteri Pendidikan Nasional Republik Indonesia Nomor 41 Tahun 2007. Jakarta: BSNP.

Basrowi dan Sukidin. 2002. Metode Penelitian Kualitatif Perspektif Mikro. Surabaya. Insan Cendikia.

Fridani,Lara dkk. 2011. Evaluasi Perkembangan Anak Usia Dini. Jakarta: Universitas Terbuka

Slamet. 2003. Belajar dan Faktor-faktor yang Mempengaruhinya. Jakarta: Rineka Cipta. 
Soemanto, Wasty. 2001. Pengantar Psikologi Pendidikan. Surabaya: Usaha Nasional. Sukmadinata, Syaodih, Nana. 2007. Metode Penelitian Pendidikan, Bandung: Remaja Rosda Karya. Undang-undang RI No.20 tahun 2003.tentang sistem pendidikan nasional.

Yamin, Martinis dan Sanan. 2013.Panduan PAUD. Jakarta: Refrensi 